\title{
Killing the Critical: A Critical Discourse Analysis of Moral Values in Government- sponsored Textbooks of Nepal
}

\author{
Mr. Saroj G. C.
}

MPhil. (Tribhuvan University), Department of English, Nesfield International College, Batuk Bhairav, Lalitpur, Nepal

\begin{abstract}
Textbooks have always been a major means of standardizing the curriculum and the activities of the students. The standardization happens through teaching the values. However, the values are transformed as discourse - the means through which the reality is known or made to be known. Informed by the insights basically founded in Critical Discourse Analysis, this paper tries to explore the valuesbeliefs about certain aspect such as family, society and nation, in school-level textbooks, especially of Nepali and Social Studies, of government schools of Nepal, and attempts to argue that the textbooks prescribed by the current curriculum are cultural production at large therefore textual. Specifically, it argues how the inculcation of critical attitude in the school children has been undermined giving rise to the pedagogy that largely emphasizes on mere knowing some values that mar the development of critical attitude in the students. As a qualitative inquiry, the article critically draws upon the ideological interpretation of the moral values, and concludes the total patterning of the content of the textbooks clearly keeps the essentialities of modern education such as critical engagement, linguistic and cognitive skills, the questioning attitude and critical thinking on the part of the students at bay.
\end{abstract}

Keywords-Critical Pedagogy, Ideology, Education, Curriculum, Critical Discourse Analysis.

\section{SETTING THE SCENE: POLITICS OF TEXTBOOKS}

Education is taken for granted as a major facilitator of enhancing holistic development of a nation, in fact, the backbone of nation's national progress. As nation imagines its progress, it simultaneously imagines of citizens- what they should be like, because, one way or the other, the citizens are development "inputs" (Street, 2002; Bhandari and Abe, 2003). School education, more primarily, the textbooks, play a major role in streamlining the overall goals of education. Unfortunately, only few researches on education and pedagogical practices have been attempted regarding the nature and design of the school textbooks in Nepal, and a very few efforts have been made to critically analyze how the curriculum and its textbooks aim to construct the children for the future. In literature of the past, what kind of values and perceptions the school textbooks try to instill in the minds of students has rarely been a matter of exploration. Therefore, how textbooks of government schools of Nepal attempt to produce an ideology - an absence of attempt to instill creativity and criticality is the basic contention of this paper.
Education system can be swerved towards what kind of citizens it aims at producing. One of the most noticeable changes in its perspective tend to be a transformation from its humanist education to purposive one. The content and pedagogical practices can be used as means of cultivating desired patterns of values (Kohlberg, 1966). Previously, education was defined as a means to cultivate human consciousness. With the rise of neoliberal social praxis, education ceases to be completely so. Education now should address "questions that concern all the manifold details by which children are to be converted into desirable types of men and women" since it is executed by incorporating advertently selected values, mostly of moral nature (Dewey, 1909, p. 1). However, thoughtful educators and psychologists have become acutely aware of the inadequacies of dealing with moral issues under the cover of mental-health or groupadjustment labels. The critical perspectives in education argue that "these mental-health labels are not really scientific and value-neutral terms; they are ways of making value judgements about children in terms of social norms and acting accordingly (Veugelers, 2011). Therefore, 
textbooks, the primary means of educating the children, need a critique for the possible ideological dimension.

Textbooks have always been a major medium of standardizing the curriculum, monitoring and guiding students' activities. The standardization happens through the values - the beliefs about certain aspects such family, society or nation. The textbooks contain diverse values, for example, related to good citizen, good boy and girl, and citizens and so on. The values are transformed as discourse (van Dijk, 2006). Discourse in this context is defined as communication of thoughts by words in a given situation and context provided with the specific speakers [the textbooks/authors] and listeners [learners] and encourages the presuppositions held by the speakers and the listeners (Jager 2001). Vaara, et al. (2010), in speaking of the discursive nature of strategic texts, say, "they communicate socially negotiated meanings, [and they] legitimate ways of thinking and acting ...” (p. 3).

Like any cultural production cannot go without introspection, so does the education system in the societies informed by flows of post-discourses ${ }^{12}$. The postdiscourses take everything under scrutiny, try to revise, redefine and question everything that is considered as "authentic" and "absolute" existence of social reality, and define it as product of human/social construction. Following this postulation, discourse of education turns out to be a "textual" production. Regarding the textuality of the textbooks, Shor (1992) writes:

As long as existing knowledge is not presented as facts and doctrines to be absorbed without question, as long as existing bodies of knowledge are critiqued and balanced from a multicultural perspective, and as long as the students' own themes and idioms are valued along with standard usage, existing canons are part of critical education. (p. 35)

This study concerns with the typical moral values presented in the school-level textbooks of government

\footnotetext{
${ }^{1}$ This article is adapted from of a chapter from author's own MPhil. dissertation entitled "What the Nation Imagines? An Analysis of Government School-level Textbooks of Nepal", submitted to Central Department of English, Tribhuvan University Campus, Kirtipur, Kathmandu, Nepal. The dissertation was funded by University Grants Commission, Nepal.

${ }^{2}$ The post-discourses are the postmodernist discourses, which aim at redefining and redrawing the existence of almost everything. See, Angermuller, J. (2018). Truth after post-truth: for a Strong Programme in Discourse Studies. Palgrave

Communications, 4(1).
}

schools of Nepal. The analysis concentrates on the explanation of the individual texts that endorse "moral" behavior: the acclaimed virtues of moral integrity such as honesty, truthfulness, hard work, sincerity and patient, on the parts of the learners. More importantly, it deals with how the values of morality are politicized to create ideological concept of citizenry. This paper reports on the results of an analysis of the moral values in the textbooks of government school of Nepal. More specifically, the two main objectives of this paper are: to explore moral values represented in the school-level textbooks and to analyze the treatment of moral values - how they are directed to inculcate an ideology that prevents students to develop a critical attitude.

\section{MORAL VALUES AND CRITICAL PEDAGOGY}

Morality is generally understood broadly as the practice, manners or conduct of human beings in relation to each other. Moral education is thus concerned with standards of behavior justified by people as right and proper and is to be conducted willingly without the interference of law (Haidt \& Kesebir 2010). Moral education has always been emphasized as one educational goal, even the most important goal. Study of moral education began to get importance with the attempts made first by Jean Piaget (1965) and more strongly by Lawrence Kohlberg $(1971,1976)$. It is an attempt to promote the development of children's and adolescents' moral cognitive structures (moral reasoning stages) in school settings.

The moral education is endorsed in modern education especially through teaching some values, deemed prominent by the existing cultural system at large. It is a way of teaching the students the process of "socialization" and "subjectification" of themselves in existing social order. After this, the students are the part of broader social structure, and begin defining themselves and their behavior accordingly. Therefore, civic learning is not always a linear and naive process. It is often political and cultural in nature and purpose (Biesta, 2009, 354). The merits and values first are taught with the purpose of developing moral integrity in individual life. Later on, they become the building blocks of national life or notion of national citizenry.

Modern social structure prioritizes one kind of social and socio-political order over other, for it embraces a set of values and rejects the other sets. Existing social order or the social system therefore cannot be value neutral and politically unbiased. Instead, it is contingent and often dominated by certain ideologies. Regarding civic learning, Biesta and et al. (2009) argue civic learning is the learning 
which occurs in and through the processes and practices that make up the everyday lives of children, young people and adults and which is closely connected to their actual condition of citizenship. Then unlike what is assumed in much curricular thinking, we should not conceive of civic learning as a linear process moving from a situation of "not-yet-being-a-citizen" to a situation of "fully-fledged citizenship" (France, 1998 as cited in Biesta, 2009, p.7).

Some critical perspectives on education postulate civic learning contributes to the reproduction of the existing socio-political order and thus to the adaptation to or insertion of individuals into this order, and those forms of civic learning that contribute to political subjectivity and agency (Lindsay, 2003; Rogers, 2017). The reflection of existing social order of socio-political reality has been tried to reproduce through the deployment of acclaimed values of moral integrity and merits. As Biesta (2011) argues, civic learning should rather be understood as non-linear, and also as recursive, and cumulative (emphasis is original). Civic learning is a non-linear process because it is closely connected to ongoing positive and negative experiences with democracy and citizenship, and thus is likely to reflect fluctuations in these experiences (p. 86).

Given that textbooks are cultural production, the content of the text is heavily influenced by historical reality in which they are produced. In this case, civic learning takes at two forms: socialization and subjectification (Biesta 2014, p. 85-86). In terms of the aims of civic learning and citizenship education, the first would see the aims of civic learning in terms of the reproduction of an ideology that supports the existing socio-political order and thus of the adaptation of individuals to this order, while the second would focus on the emergence of political agency and thus sees the aims of civic learning first and foremost "in terms of the promotion of political subjectivity and agency" (Biesta, 2011, p. 88).

\section{MORAL VALUES AND IDEOLOGICAL SOCIALIZATION}

School textbooks and teachers can be neutral only in circumscribed areas. The textbooks, along with their primary objective of teaching the students - making them conscious, are designated with intention of teaching something more. The content of the textbooks brings diverse kind of topoi: community, morality, family, government, culture and so on. The commonplace topics embed values that tacitly tries to orient and influence the learners toward learning those values in particular direction or purpose. The values may differ in terms of the political and cultural changes the nation has undergone. However, they stand for the ideological socialization ${ }^{3}-$ the way in which people acquire values and opinions that shape their political stance and ideology, however.

On how textbooks function and are functionalized, Apple (1992) argues that textbooks are the major ideological transmitter for conveying dominant beliefs and values of the society. Similarly, Cortazzi and Jin (1999) claim that a textbook potentially functions as a teacher, a map, a resource, a trainer, an authority, and an ideology. Like an ideology, a textbook reflects a worldview of a cultural system of which moral values are a sub-system. There are again different values and associations how a teacher should be perceived. This makes textbooks play a pivotal role in the success of language education's socially transformative agenda what is to be transferred.

Regarding the politics of the official knowledge, Apple argues education is deeply implicated in the politics of culture. In his words, "the curriculum is never simply a neutral assemblage of knowledge, somehow appearing in the texts and classrooms of a nation. It is always part of a selective tradition, someone's selection, some group's vision of legitimate knowledge" (Apple 2000, p. 1). It is produced out of "the cultural, political, and economic conflicts, tensions, and compromises that organize and disorganize people" (p. 2). Apple's notion of developing curriculum suggests the design of texts of is already always influenced by the official [national] culture.

Moreover, Althusser's notion of education as state apparatus adds a credential delineation to this logic of Apple. In his book Lenin and Philosophy, he argues that education is the most important ideological state apparatus. $\mathrm{He}$ argues the education system teaches the students the dominant discourses, techniques, and the customs of the society from four to above years, from nursery to the university classes, for several hours a day. The students learn the ruling ideologies directly in the form of morals, religion, and philosophy. The schools and colleges teach both the vales and knowledge and necessary skills to support the existing political and economic system (144146). If looked through the Marxist eyes, reproduction of middle-class propriety is the basic concern of the school texts. The standard content textbook materials should be subject to problematizing and critique though they can be used in the classroom.

\footnotetext{
${ }^{3}$ See Glasberg, Davita Silfen; Shannon, Deric (2011). Political sociology: Oppression, resistance, and the state. Thousand Oaks: Pine Forge Press. p. 56.
} 


\section{TEXTBOOKS AND CRITICAL DISCOURSE ANALYSIS}

This paper basically engages case study method along with descriptive content analysis to gain an in-depth understanding of the topic under investigation. As a qualitative research practice, the case study method raises a question about something that perplexes and challenges themind (Merriam 1998, p. 57). However, more intervening stance is exerted through critical discourse analysis (Wodak\& Meyer, 2015; Chouliaraki \& Fairclough, 1999; van Dijk, 1997; Jager, 2015).

This research takes in the cases of three course books ${ }^{4}$, Nepali Subject of Class six, seven and eight (traditionally, the lower secondary level). This selection represents a "single unit" or "bounded system" (Duff 2008). The course of book of grade six, seven and eight consist of 20,21, 22 units respectively, and each lesson is followed by almost same number and nature of exercises. As Creswell points out, data collection in a case study involves using multiple sources (Creswell 1998, p. 65). Accordingly, it included the pages/units of the coursebooks to figure out the moral values as well as learning activities to analyze the research objectives as stated previously.

Since the Critical Discourse Analysis regards any textbooks as the cultural artifacts- an object of analysis shaped by political and historical parameters, it is more appropriate to the purpose of examining the cultural values they carry. Moreover, this study also uses content analysis as it deploys "a set of procedures to make valid inferences from text" (Weber, 1990, p. 9). Content analysis can help to examine texts as carrier of cultural information- values and beliefs (Krippendorff 2008). However, this approach fails to delineate the conduit- how the content of textbooks potentially engages learners in the process of moral meaning making. Then critical discourse analysis comes into play and seems useful because it explains the trajectories the discourse produces in knowledge making (Jager, 2015). Moreover, how effective is the idea of encompassing moral values as learning sources is analyzed with scrutiny of learning activities. Therefore, content in this study is understood both as the texts and the accompanying learning tasks in the textbooks.

There are two possible approaches to starting a content analysis: by setting a number of categories that will be followed throughout the textbooks or by reading the textbook first and at the same time deriving a list of categories that seem most salient (Pingel, 2010). In this study, selecting the criteria for the analysis of the studies, second approach was adopted. First, without drawing upon any preconceived groupings, I went through all the course books under analysis to get the whole picture of moral values in the textbooks. Then in the next readings I created a list of moral values that were embedded in the examined course books and created a matrix of those values.

The process of data analysis first began with exploring the content- message of the moral values. Next, the learning activities/exercises were analyzed to check if they possibly engage learners to understand the socially constructed meaning of the values. The discussions of the finding were informed by critical discourse analysis, which stresses on "it focuses on how social relations, identity, knowledge and power are constructed through written and spoken texts in communities, schools and classrooms" (Luke, 1997, p. 51).

\section{TEXTUAL CULTIVATION OF MORALITY}

\section{Moral Content.}

The results of the content analysis show that quite limited moral values are covered in the three examined course books, and those moral values are largely embedded in the reading texts (see Table 1). The most repeated themes and topics the selected units comprise are: Family, Social Relationship, Cultural Identity, Environmental Issues, Technology (rarely), Civic Education, Myths and Biography, are expanded throughout grades (6-8) but dealt with from different perspectives and at different levels cognitive complexities with an aim of catering for the students' intellectual and cognitive development. As shown in Table 1 , topics in the reading texts cover a limited number of moral values: mutual help or cooperation, giving up the personal interests, wit is better than might/might cannot stand the wit, respectful to power and might, obedient to god, virtue of Bhakti (worshiping for some personal interests), patience, cheating, altruism and kindness, anger, importance and benefits of joint living, love and family ethics. These are not only Nepali traditional values, but also universal values.

\footnotetext{
${ }^{4}$ All the books were published by Curriculum Development Centre, Ministry of Education, Government of Nepal, Sanothimi, Bhaktapur.
} 
Table 1: Moral Values in Textbooks

\begin{tabular}{ll} 
Grade/ & Example Drawn from the Texts \\
Unit & \\
\hline $6 / 7$ & Saane and Thule have a buffalo called Moti $^{5}$ which poses a problem in their property \\
allocation process. However, the Mukhiya (chief of the values) decides solves the \\
issue by proposing that they would take care of the buffalo in mutual cooperation: \\
Saane chose the from side, and Thule chose the rest. Saane manages grass and feeds \\
\\
Moti well but Thule as he chose the back enjoyed the milk without contributing any \\
labour. This could not go for long. Saane stopped looking after Moti. Thule and \\
Sanay come to compromise when Thule does not see any possibility for the better \\
except accepting Saane (p. 45-52).
\end{tabular}

6/2 The fable "Yukti Saamu Shakti Tikdaina" (Might cannot Stand Wit), dramatizes a contest between might, represented by Chaturdant, and wit, represented by Lambakarna, in which Lambakaran shows the power of his wit, and becomes able to chase Chaturdanta away from his abode, restoring peace for him as well for his fellow dwellers (p. 7-15).

\begin{tabular}{|c|c|}
\hline $\begin{array}{l}6 / 3 \\
\& 10\end{array}$ & $\begin{array}{l}\text { 1. Only human society has the capacity to move ahead and lead the society ahead. } \\
\text { We should move ahead, and protect the virtue of tolerance, peace, help, } \\
\text { brotherhood, humanity and freedom. The good works and behaviors make } \\
\text { humans as respectful as the gods themselves (16-19). }\end{array}$ \\
\hline & $\begin{array}{l}\text { 2. The king, Mabohaang decides to go for a hunting. However, the deer, a prey of } \\
\text { the King, is mysteriously lost despite being chased by preying dogs and soldiers } \\
\text { from all side. This happens to be an ordeal for the king by a goddess, Yumadevi, } \\
\text { to check if he possesses a good heart. By rejecting the ministers' proposal to } \\
\text { marry the beautiful girl suddenly encountered in dense and sudden jungle, the } \\
\text { king proves his respect for her, and instantly becomes the devotee of powerful } \\
\text { goddess, Yumadevi. Though the king possesses might, he does succumb to the } \\
\text { greater power. Yumadevi praises king's complete devotion and his respect of } \\
\text { power. He is delighted to have seen the supernal being, and is determined to be a } \\
\text { complete devotee of the goddess and continue the rule (p. 65-72). }\end{array}$ \\
\hline
\end{tabular}

6/12 An adapted mythological story "Test of Yudhisthira" illustrates some famous "ethical" dictums of popularized by Hindu religion: "truth always wins; patience is the friend during danger; happiness is sure to come after sadness" (p. 86-89).

7/2 The story "Nephew Who Corrected Maternal Uncle" tries to demonstrate the importance of being honest, not cheating other. In other words, it tells how you can teach a lesson to the person who is always a fraud and dishonest. Maternal uncle is lazy and believes in cheating for his survival, and Bhanajo does not like and makes preparation to teach a lesson to maternal uncle. Ironically, he takes the illogical means to teach him a lesson and make him realize his mistakes. First, he uses a horse, and sells it to the uncle promising him that the horse excretes pearls. But this does not happen, and Bhanjo blames uncle that uncle forgot to revolve around and make a sacred greeting to the horse. Second, he uses a rabbit, which can work an errand-runner, and is capable of understanding human language. But, the rabbit, when tested, fails to accomplish the task. Mama, so furious, asks the explanation. Bhanaja again blames Mama that Mama forgot to show his own home. Therefore,

\footnotetext{
${ }^{5}$ The textbooks selected for analysis are in Nepali language. In order to avoid Romanized language thus maintain a uniformity, the content, except the names of the persons and places, has been translated in English by the author of this article himself. 


\begin{tabular}{|c|c|c|}
\hline & $\begin{array}{l}\text { the rabbit could not deliver the massage. Finally, Bhanaja tricks Mama to throw } \\
\text { Mama into the river so that he will obtain an ultimate realization that cheating is } \\
\text { self-destructive (P. 6-10). }\end{array}$ & \\
\hline $7 / 14$ & $\begin{array}{l}\text { "The Story of Bodhisatwa" recounts a sacrifice made by the eponymous character. } \\
\text { He sacrifices his life as supply to a hungry tigress, who in turns becomes able to } \\
\text { feed her child. The person is supposed to have reincarnated as Siddhartha Gautam } \\
\text { Buddha (p. 103-106) }\end{array}$ & $\begin{array}{l}\text { Altruistic and kind } \\
\text { people land in } \\
\text { heaven, and deserve } \\
\text { happiness and } \\
\text { comfort in the next } \\
\text { life. }\end{array}$ \\
\hline s7/16 & $\begin{array}{l}\text { "Anger and Monster" deploys the characters from the epic of Hindu mythology, The } \\
\text { Mahabharata, and shows a fight between Saatyaki and a monster, and later } \\
\text { Balaram and the monster. Monster has an uncanny and mysterious characteristic- } \\
\text { the angrier he becomes the more gigantic he grows. Balaram understands this } \\
\text { mystery, and tries to keep him happy, so that the monster is reduced to a toy-size } \\
\text { thus easily capture (p. 117-120). }\end{array}$ & $\begin{array}{l}\text { Anger is self- } \\
\text { destructive and is } \\
\text { only possessed by } \\
\text { the people like } \\
\text { monsters. }\end{array}$ \\
\hline $7 / 21$ & $\begin{array}{l}\text { "Thick Pulse" dramatizes a story where the narrator's friend, Harihar, breaks the } \\
\text { news that he has decided to leave the parents and begin living alone. The narrator is } \\
\text { surprised by the news. In response he recounts the story of another friend, who also } \\
\text { made the same decision. But, in long run, the decision has damaging consequences. } \\
\text { (p. 146-50) }\end{array}$ & $\begin{array}{l}\text { Morality pertinent to } \\
\text { importance and } \\
\text { benefits of joint } \\
\text { living. }\end{array}$ \\
\hline $8 / 19$ & $\begin{array}{l}\text { "Story of Lion and Fox" showcases relationship between lion and fox, the animals } \\
\text { from disparate genus, living together. When they grow up, misunderstanding } \\
\text { between them crops up. The Lions want to prey while the fox does not even the it } \\
\text { was nourished by the lioness (p. 127-30). When lioness tries to teach that it is } \\
\text { supposed to act according to the propriety of clan, the fox runs away. }\end{array}$ & $\begin{array}{l}\text { The surrenders } \\
\text { should be protected; } \\
\text { one should not go } \\
\text { against the propriety } \\
\text { of clan. }\end{array}$ \\
\hline
\end{tabular}

\section{Learning Activities}

The moral content of the units is always followed by the learning activities, exercises. The chosen books: Nepali textbook of grade 6,7 and 8, contain 20, 21 and 22 lessons respectively. Each unit contains 19 exercises on the average. Overall, there are 1, 197 numbers of major exercises (excluding the bullets and sub-points that may come under the major exercise). Major topics of exercise entail ditto-reading, reproducing the information - procreating the information given in the content, answering the short questions, grammar-based questions termed as Functional Exercises and Creative Exercises.

Each lesson contains at maximum rate 2 exercises under the topic Creative Exercise. Following the calculations, only 126 exercises are there altogether in these three textbooks, which is just below the nine per cent. These facts conclude how little has been tried to empower creativity and criticality in students.

Greater portion of the exercises concentrates on the reproduction of the information given in the content. After that, focus has been given to the grammar learning.
And, least focus has been given to critiquing, evaluating, synthesizing, and creating. The exercises that come under the "Creative Exercise" are rarely creative in their spirit. Most of them are repeated. For example, wherever a story is a reading content, the creative exercise is writing a story, either by jotting down the given points or asking a folktale with parents or caretakers.

\section{PRODUCTION OF DISCOURSE AND ITS MATERIALIZATION}

The findings of the content analysis indicate that a certain number of moral values are embedded in the reading texts of the textbooks for school students. These values are largely part of moral values system so far taught in Nepali social system. Beside these, there are universal moral values such as honesty, peace-loving, and cultural tolerance. It can be inferred from these results that morality was considered while the texts were selected. The textual construction of moral values takes two dominant dimensions: the values are endorsed to produce middle class ideology, and students are not given a space to think critically, judge them and give a response. As prefaced in all the three books, the general objective of these textbooks is to make education goal- 
oriented, practical, contextual and employment-oriented. The preface clearly delineates that promotion of the social and characteristic virtues and virtues related to character like honesty, self-esteem, independence, morality and discipline is one of the specific objectives of the course books. ${ }^{6}$ However, the content selected for teaching these "virtues" and values are designed in a such a way that give rise to cultivation of leniency and obedience on the part of the learners.

\section{Reproduction of Middle-class Values}

The moral values delineated in the reading content of the text get through because of the felicity conditions- criteria that must be satisfied for an expression to achieve its purpose. The conditions in this context could be described as "[. . . .] educational discourses hold that a child's body is a passive textual surface on which moral values should be inscribed by teachers and senior kin, who are expected to guarantee a child's successful "socialization" (Rydstriim, 2001, p. 395). Moreover, the educational discourses already enjoy greater level of humanistic eulogy- education as a means of liberating from the obscurantism. Therefore, the preaching of the moral values and cultural agendas become easier.

The results of the content analysis show that the ethics of propriety is pinned down to the ethos of middleclass values ${ }^{7}$ and their cultural consciousnesscautiousness about moral propriety not to cross the limit, not to go beyond the given space of social and cultural freedom. The culture of propriety urges people to seek for the freedom within permitted sphere of socially given. The individuals are asked to act use their freedom only the given space of consumption, fashion, celebration and other various forms of cultural practices. Such values [of middle class] are "tied down" by the restraint of social order, so to legitimize its own predicament; they constitute moral stories of "proper" and "acceptable" limits between two different class positions: the high class and the low class (Liechty, 2008, p. 67).

In such cultural practices, the individual subjects are not supposed, in fact, suggested not to take the risk of questioning the anomalies, gaps, incongruities,

\footnotetext{
${ }^{6}$ See the preface: Bhattarai, B. and et al. (2018). Nepali Grade7. Bhaktapur: Curriculum Development Center, Ministry of Education, Government of Nepal, and also coursebooks of the same subject at different level.

7 See Power, S., Edwards, T., Whitty, G. \& Wigfall, V. (2002)

Education and the middle class (Buckingham, UK, Open

University Press). Also see, Lamy, P., \& Levin, J. (1985).

Punk and middle-class values: A content analysis. Youth \&

Society, 17(2), 157-170.
}

ISSN: 2456-7620 irregularities and discrepancies that lie underneath such cultural maneuverings. It does not mean that the textbooks totally lack the texts that promote curiosity and questions but the point is: despite inclusion, they appear to be controlled by the other power lessons that suggest students not to go beyond. Moreover, the patterning of the learning sources never allows the space of/for the critical thinking.

This logic is the effort to secure the unique cultural space through negotiation between the high and the low class in the Nepali society (Liechty 37-38). Such designation echoes the propriety in consumption or the middle path for the cultural reproduction of the middleclass people. This sense of propriety is based on the tendency of confirmation to the existing culture and the social order rather than on the critical questions the people should ask. The designation of textbooks is in commensurate with the existing cultural practices proper, which are necessitated fundamental virtue to be a national citizen, it supports. Any divergent or any kind of going beyond the set limit is construed culturally bad and improper. This kind of fixation demanded on the part of learners shuns any kind of resistance, criticism, or questioning even if at the time of need.

Looked from the critical approaches, apart from fulfilling the basic need for learners to develop enough language to transmit messages, these content textbooks offer little space in which learners are encouraged learners (and teachers too) to think critically. Similarly, there is no sufficient amount of reasoning to support why we are teaching and what society we are teaching for.

When examined from the critical pedagogy, the text content presents another problem- the state of complacency. The text content depicts life/social reality as too beautiful, peaceful and perfect without any problems or concerns and people leading a care-free life, everyone being nice to everyone else. The dark side of the life (Rinvolucri, 1999) has completely been ignored. Many moral issues of the Nepali contemporary society such as gender discrimination, untouchability, casteism, drug addiction and selfishness, class conflict, gender inequality and so on are largely absent in the textbooks. The inclusion of those themes in the coursebook would help to invoke students' critical discussion and analysis because they are derived from the students' real-life situations, needs, and interests.

Excising Exercises: No Space for Criticality and Creativity 
While the coverage of the moral values was relatively comprehensive, the learning activities fall short in encouraging the learners when they are looked from the critical pedagogy perspective. As revealed in the examples of learning activities presented above, the textbooks emphasize the acquisition of rules related to linguistic knowledge such as grammar and vocabulary rather than development critical attitude and creative faculty. Even the acquisition of linguistic and communicative competence focuses on reproduction of the same information and the rules explicitly stated in the reading content.

Regarding the learning activities promoted in the textbooks, they appear to accentuate students' mechanical practice of the target linguistic structure, rather than the empowerment of the students by encouraging them to raise their voice about the topic in question through critical discussion. All the reading texts are followed by the same question-answer format to check the students' comprehension of the in-text factual information only. For example, in Unit 10 (Grade 8), a story "One Evening" is followed by 8 exercises that topically ask student to reproduce the information that is (questions requiring short answers) already presented in simple language in the reading content; following this, 11 exercises are related to grammar that include dictation, antonyms and synonyms, and multiple-choice questions on wordmeaning and spellings. The labeling and nature of the questions is mechanical and is often repeated.

Rarely are there learning activities that engage students in reading, writing, observing, debating, role play, simulations, and the use of statistical data to develop skills in critical thinking, decision making, and problem solving. Put differently, most of the learning activities in the textbooks are only targeted at the exchange of messages at the expense of issues of students' voice and identity. What is lacking in content textbooks is rigorous and profound understanding of critical pedagogy. In short, the resources lack vigor of learning and teaching for social justice, in ways that support the development of active, engaged citizens who will, as circumstances permit, critically inquire into why the lives of so many human beings, perhaps including their own, are materially, psychologically, socially, and spiritually inadequate- citizens who will be prepared to seek out solutions to the problems they define and encounter, and act accordingly (Crookes, 2013, p.8).

Active learning prepares the learners to know about the existing problems of the society and culture, and asks them to develop themselves to prepare for the real-life problems. Mullins (1990) recommends active ISSN: 2456-7620 learning as ideal for teaching topics like civic and moral education. He opines that in active learning "the passive transmission of facts is rejected as an inappropriate method of teaching that should be modified in favor of active approaches to learning" (p.4). Students are to engage in reading, writing, observing, debating, role play, simulations, and the use of statistical data to develop skills in critical thinking, decision making, and problem solving (Bean, 2011). Cooperative and collaborative types of learning should also be emphasized.

\section{CONCLUSION}

While moral education is not explicitly articulated in the syllabus document, it is implied in reading content. Moral values imbibe an ideology that attempt to make the learners passive, less defiant and critical. The purpose of the content designed in the textbooks, as observed, is to teach students about the values, attitudes, and standards of appropriate behavior prevailing in their immediate social environment. The textbooks rarely consider about developing students' capacity to critically judge those values.

Nepal as nation grappling to ensure quality education puts much emphasis on learning the content (Mathema 2007; Graner, 2006, p.168-69). Hence, the textbook's knowledge is considered to be authoritatively valid. The absence of activities that encourage critical awareness in the course book is likely to lead students to accept passively their places in society rather than to take a more active role in determining their experiences and their positions within society in order to transform the society.

To address the limitations regarding the learning activities in textbooks of government schools, I suggest a critical pedagogy which "prepare[s] learners to be both global and local speakers and to feel at home in both international and national cultures" (Kramsch and Sullivan 1996, p. 211). Such an approach does not see critical thinking, rationality, and moral education as an automatic and natural byproduct of foreign language learning. Instead, it focuses on developing students' linguistic proficiency, critical thinking, moral education, and rationality so that language acquisition, language use and the worldviews, ideologies, and other kinds of knowledge are inculcated in activities along with language. Following this approach, textbooks should provide learning activities that "generate discussions and arguments which are essential for the development of critical thinking skills as well as positive character traits (Shaaban 2005, p. 204)." 


\section{ACKNOWLEDGEMENTS}

I would like to extend my immense gratitude to Prof. Dr. Anirudra Thapa, Central Department of English, Tribhuvan University, Nepal, for his theoretical insights in shaping this article. Similarly, many thanks to Prof. Dr. Ramchandra Poudel, Dean of Faculty of Social Sciences, Nepal Open University, for his consistent guidance. My better half, Laxmi Adhikari and dear friend, Rocky Maharjan, also deserve many thanks for their continuous encouragement.

\section{REFERENCES}

[1] Althusser, L. (2006). Lenin and philosophy and other essays. Aakar Books.

[2] Angermuller, J. (2018). Truth after post-truth: for a Strong Programme in Discourse Studies. Palgrave Communications, 4(1). doi:10.1057/s41599-018-0080-1

[3] Apple, M. W. (1992). The text and cultural politics. Educational Research; 21(7), 4-19.

[4] Apple, M. W (2014). Official knowledge: Democratic education in a conservative age. Routledge.

[5] Bean, J. C. (2011). Engaging ideas: The professor's guide to integrating writing, critical thinking, and active learning in the classroom. John Wiley \& Sons.

[6] Bhandari, B. B. \& Osamu Abe. (2003). Education for sustainable development in Nepal: views and Visions. Japan: International Institute for Global Environmental Strategies (IGES).

[7] Bhattarai, B. and et al. (2018). Nepali Grade-6. Bhaktapur: Curriculum Development Center, Ministry of Education, Government of Nepal.

[8] Bhattarai, B. and et al. (2018). Nepali Grade-7. Bhaktapur: Curriculum Development Center, Ministry of Education, Government of Nepal.

[9] Biesta, G. (2011). Learning democracy in school and society: Education, lifelong learning, and the politics of citizenship. Springer Science \& Business Media.

[10] Biesta, G., Lawy, R., \& Kelly, N. (2009). Understanding young people's citizenship learning in everyday life: The role of contexts, relationships and dispositions. Education, citizenship and social justice, 4(1), 5-24.

[11] Biesta, G. (2010). On the weakness of education. Philosophy of Education Yearbook: 354-362. Retrieved from http://orbilu.uni.lu/bitstream/10993/7817/1/ 11220PUB\%20PES\%202010\%20Weakness.pdf

[12] Chouliaraki, L., \& Fairclough, N. (1999). Discourse in late modernity: Rethinking critical discourse analysis. Scotland: Edinburgh University Press.

[13] Cortazzi, M., \& Jin, L. (1999). Cultural mirrors: Materials and methods in the EFL classroom. In Hinkel, E. (Ed.) Culture in second language teaching and learning.

[14] Creswell, J. W. (1998). Qualitative inquiry and research design: Choosing among five traditions.
[15] Crookes, G. V. (2013). Critical ELT in action: Foundations, promises, praxis. London: Routledge.

[16] Duff, P. A. (2008). Case study research in applied linguistics. New York: Lawrence

[17] Glasberg, D. S. \& Deric Shannon. (2011). Political sociology: Oppression, resistance, and the state. Thousand Oaks: Pine Forge Press.

[18] Graner, Elvira. (2006). Education in Nepal: Meeting or missing the millennium development goals? Contributions to Nepalese Studies, 33(2), 153-175.

[19] Haidt, J., \& Kesebir, S. (2010). Morality. Handbook of social psychology.

[20] Hardy, C. \& Phillips, N. (2004). Discourse and power. The Sage handbook of organizational discourse, 299-316.

[21] Jäger, S., \& Maier, F. (2014). Analyzing discourses and dispositives: a Foucauldian approach to theory and methodologies. Methods of critical discourse analysis. 3 rd Ed. London: Sage.

[22] Kohlberg, L. (1966). Moral Education in the Schools: A Developmental View. The School Review, 74(1), 1-30. Retrieved from http://www.jstor.org/stable/1084286

[23] Kohlberg, L. (1981). Essays on moral development. Volume one: The philosophy of moral development (New York, Harper and Row).

[24] Kramsch, C., \& Sullivan, P. (1996). Appropriate pedagogy. ELT Journal, 50, 199-212.

[25] Krippendorff, K. (2008). Content analysis: An introduction to its methodology. Thousand Oaks: Sage.

[26] Lamsal, R. \& Ram P. Gnawali. (2018). Nepali Grade-8. Bhaktapur: Curriculum Development Center, Ministry of Education, Government of Nepal.

[27] Liechty, M. (2003). Suitably modern: Making middle-class culture in a new consumer society. Princeton University Press.

[28] Lindsay, G. (2003). Inclusive education: A critical perspective. British journal of special education, 30(1), 312.

[29] Luke, A. (1997). Theory and practice in critical discourse analysis. International encyclopedia of the sociology of education, 8, 50-57.

[30] Mathema, K. B. (2007). Crisis in education and future challenges for Nepal. European bulletin of himalayan research, 31, 46-66.

[31] Merriam, S. B. (1998). Qualitative research and case study applications in education. San Francisco: JosseyBass.

[32] Mullins, S. L. (1990). Social studies for the 21st century: Recommendations of the National Commission on social studies in the schools. ERIC Clearinghouse.

[33] Pennycook, A. (1990). Towards a critical applied linguistics for the 1990s. Issues in Applied Linguistics, 1(1), 8-28.

[34] Pennycook, A. (2001). Critical applied linguistics: A critical introduction. Mahwah: Lawrence Erlbaum.

[35] Piaget, J. (1965). The moral judgment of the child. New York: The Free Press. 
[36] Pingel, F. (2010). UNESCO guidebook on textbook research and textbook revision. Paris: UNESCO.

[37] Power, S., Edwards, T., Whitty, G. \& Wigfall, V. (2002). Education and the middle class (Buckingham, UK, Open University Press).

[38] Rashidi, N., \& Safari, F. (2011). A model for EFL materials development within the framework of critical pedagogy (CP). English Language Teaching, 4, 250259.

[39] Ryan, K. (1986, November). The new moral education. Delta Kappan, p. 228-233.

[40] Rogers, R. (2004). An introduction to critical discourse analysis in education. In An introduction to critical discourse analysis in education (pp. 31-48). Routledge.

[41] Rydstriim, H. (2001). Like a white piece of paper: Embodiment and the moral upbringing of Vietnamese children. Et/mos, 66, 394-413.

[42] Shaaban, K. (2005). A proposed framework for incorporating moral education into the ESL/ EFL classroom. Language, Culture and Curriculum, 18, 201217.

[43] Shor, I. (1992). Culture wars: School and society in the conservative restoration. Chicago: The University of Chicago Press.

[44] Street, B. V. (2002). Literacy and Development: Ethnographic Perspectives. Routledge.

[45] Van Dijk, T. A. (1993). Principles of critical discourse analysis. Discourse \& society, 4(2), 249-283.

[46] Van Dijk, T. A. (2006). Ideology and discourse analysis. Journal of political ideologies, 11(2), 115-140.

[47] Veugelers, W. (Ed.). (2011). Education and humanism: Linking autonomy and humanity. Springer Science \& Business Media.

[48] Weber, R. P. (1990). Basic content analysis (2nd ed.). Newbury Park: Sage.

[49] Wodak, R., \& Meyer, M. (Eds.). (2015). Methods of critical discourse studies. Sage.

[50] Wringe, C. (1998). Reasons, values and community in moral education. British Journal of Educational Studies, 46(3), 278-288. Retrieved from http://www.jstor.org/stable/3122084 